\title{
False Positive Result in the Whole-Body Scan with 131-I in the Follow-up of Differentiated Thyroid Cancer: The Fistula Tract Accompanied by the Suture Granuloma
}

\author{
Diferansiye Tiroid Kanserinin Takibinde Tüm Vücut I-131 Tarama ile Yalancı Pozitiflik Nedeni: Sütür Granülomuna \\ eşlik eden Fistül Traktı
}

\section{Zuhal Kandemir ${ }^{1}$,Sabire Yılmaz Aksoy ${ }^{1}$, Elif Özdemir ${ }^{1}$, Cevdet Aydın $^{2}$, Nilüfer Yıldırım ${ }^{1}$, Şeyda Türkölmez ${ }^{1}$}

${ }^{1}$ Ankara Atatürk Training and Research Hospital Department of Nuclear Medicine, Ankara, Turkey

${ }^{2}$ Ankara Atatürk Training and Research Hospital Department of Endocrinology, Ankara, Turkey

\section{ABSTRACT}

The role of radioiodine-131(I-131) Whole- body scan (WBS) is crucial regarding the management of patients with differentiated thyroid carcinoma (DTC) in detecting normal thyroid remnants and recurrent or metastatic disease. Although I-131 is a sensitive marker for detection of thyroid cancer, radioiodine uptake is not specific for thyroid tissue. According to several reports, various tissues or non-thyroidal pathologic processes were associated with falsepositive WBS with radioiodine. In this case report we reported that the false positive result was present due to the fistula accompanied by the suture granuloma. A 47 year-old woman underwent total thyroidectomy for papillary thyroid carcinoma.A false-positive iodine uptake in the midline neck was determined by a diagnostic I-131 whole body scan. I-131 whole body scan was correlated with ultrasonography (US) and computed tomography (CT) imaging features, biochemical data, clinical history, and physical examination. The lesion was demonstrated to be a fistula tract accompanied by the suture granuloma. The false- positive findings in the I-131 whole-body scan should be confirmed with other imaging modalities, available biochemical data, clinical history, and physical examination in order to avoid unnecessary treatments.

Key Words: Differentiated thyroid cancer, false- positive I-131 whole body scan, fistula, suture granuloma

Received: 02.11 .2016

Accepted: 04.24.2016

\section{ÖZET}

Differansiye tiroid kanserleri takibinde kullanılan I-131 tüm vücut taraması, postoperatif normal rezidü tiroid dokusu ve rekürren/metastatik hastalıkları tespit etmede ve tedavinin belirlenmesinde önemli bir rol oynar. I-131, tiroid kanseri tespiti için duyarlı bir gösterge olmasına rağmen radyoaktif iyot tutulumu tiroid dokusu için spesifik değildir. Birçok hastada tüm vücut taramasında yanlış pozitif yoruma neden olabilecek anatomik varyantların ve farklı fizyolojik tutulumların yanısıra tiroid dışı nedenlere bağlı olarak da tutulumlar görülebilir. Bu olgu raporunda yanlış pozitif sonuca neden olan sütür granülomuna eşlik eden fistül traktı sunulmuştur. 47 yaşında papiller tiroid kanseri nedeniyle total tiroidektomi operasyonu geçiren bayan hastaya tanısal amaçı yapılan I-131 tüm vücut taramasında, boyun orta hatta yanlış pozitif iyot tutulumu tespit edilmiştir. I-131 tüm vücut taramasında tespit edilen bu tutulum; biokimyasal veriler, klinik öykü, fizik muayene, ultrasonografi (US) ve bilgisayarlı tomografi (BT) görüntüleme yöntemleri ile korele edilmiş ve lezyonun sütür granülomuna eşlik eden bir fistül traktı olduğu saptanmıştır. I131 tüm vücut iyot taramada izlenen yanlış pozitif bulgular, gereksiz tedavileri önlemek için diğer görüntüleme yöntemleri, mevcut biyokimyasal veriler, klinik öykü, fizik muayene ile korele edilmelidir.

Anahtar Sözcükler: Diferansiye tiroid kanseri, yanlış pozitif I-131 tüm vücut görüntüleme, fistül, sütür granülomu

Geliş Tarihi: 11.02 .2016

Kabul Tarihi: 24.04 .2016

\section{INTRODUCTION}

The role of I-131 WBS is crucial regarding the management of patients with DTC in detecting normal thyroid remnants and recurrent or metastatic disease. Although I-131 is a sensitive marker for detection of thyroid cancer, radioiodine uptake is not specific for thyroid tissue. According to several reports, various tissues or non-thyroidal pathologic processes were associated with falsepositive WBS with radioiodine (1-4)

In our report, the patient is presented with a false-positive uptake caused by the fistula accompanied by the suture granuloma in postoperative thyroid bed. To the best of our knowledge, although different false-positive results in I-131 WBS have been described, it is an interesting case of this kind in the literature.

\section{CASE REPORT}

A 47-year-old female patient who had history of bilateral total thyroidectomy diagnosed as $1 \mathrm{~cm}$ follicular variant papillary cancer in the right lobe of thyroid. The patient underwent $3.7 \mathrm{GBq}(100 \mathrm{mCi})$ radioiodine ablation therapy when the thyroid stimulating hormone (TSH) was $131 \mathrm{ulU} / \mathrm{mL}$, serum thyroglobulin (Tg) was $<0,2 \mathrm{ng} / \mathrm{mL}$ and serum anti-thyroglobulin (Anti-Tg) was $147 \mathrm{ng} / \mathrm{mL}$. The post-therapy WBS was performed on a dual head gamma camera (Infinia-General Electric Medical Systems), using a high-energy collimator, 7 days after I-131 administration. WBS demonstrated radioiodine uptake at the thyroid bed. After 6 months, a diagnostic whole body radioiodine scan with $5 \mathrm{mCi}$ radioactive iodine-131 was performed. 
I-131 administered orally and after 48 hours whole body and static neck images were acquired which demonstrated a focus of low grade radioactive iodine accumulation at the thyroid bed (Figure 1A-1C). At the time of diagnostic scan, the stimulated Tg level was $0,187 \mathrm{ng} / \mathrm{mL}$, Anti-Tg was $159,9 \mathrm{U} / \mathrm{mL}$ and US showed that there were macrocalcifications at the lateral part of the bilateral thyroid region consistent with postoperative suture materials. The stimulated $\mathrm{Tg}$ and Anti-Tg levels were undetectable in the 1st year of follow-up. However, during this period, the radioiodine accumulation at the thyroid bed persisted (Figure 1B-1D). On physical examination, we found that there were erythema and the opening of fistula on the skin located at the operation region in the neck (Figure 1E). US demonstrated that $19.5 \times 6 \mathrm{~mm}$ hypoechoic solid lobulated lesion with multiple milimetric calcifications (suture materials) at the thyroid bed which was consistent with suture granuloma (SG) and a fistula tract extending from this lesion to the skin (Figure 2A). CT images revealed fistula tract appearance at the isthmic level of thyroid bed (Figure 2B).

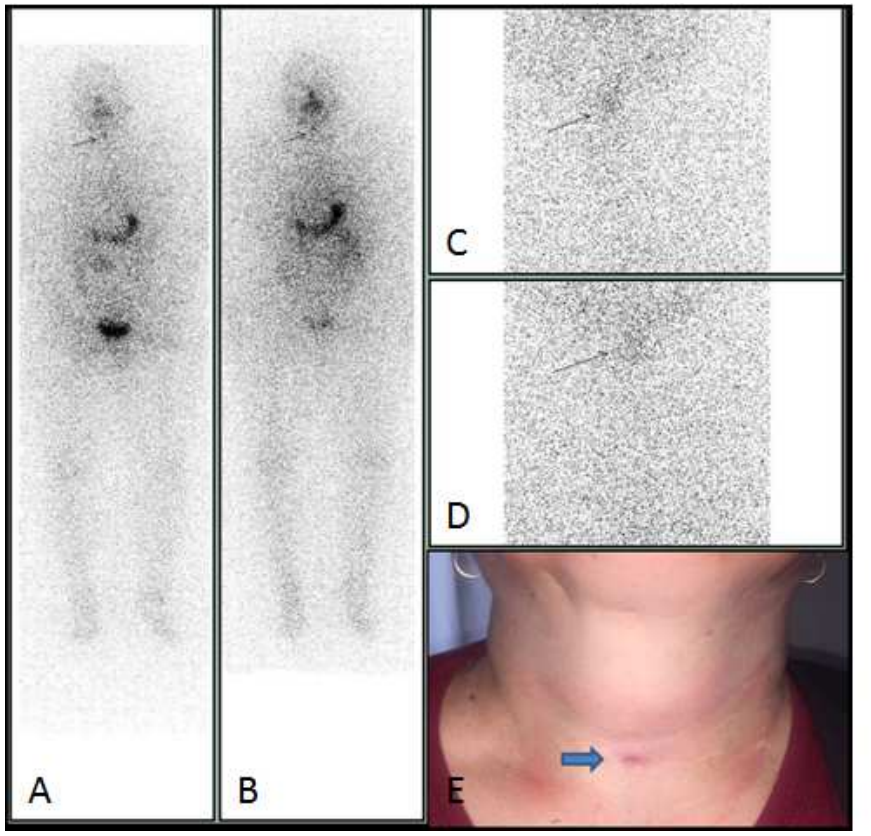

Figure 1: A diagnostic whole body radioiodine scan (A-B) and anterior static image of neck (C-D) acquired six mounts and 1 year after radioiodine treatment demonstrated a suspicious focus of low grade radioactive iodine accumulation at the midline thyroid bed. At the same region, an opening of fistula was noted also (E).

\section{DISCUSSION}

I-131 WBS and Tg measurement are used as reference methods for the patients with DTC in terms of detecting the residual tissue or metastases after thyroidectomy. False-positive WBS findings mimicking metastases of DTC have long been reported (5-9).

Regarding a study of 11 cases and available literature review; the classification of false-positive accumulations of I-131 on WBS can be done concerning the underlying pathophysiological mechanisms:external and internal contaminations by body secretions, ectopic normal thyroid and gastric tissues, inflammatory and infectious diseases, benign and malignant tumors, cysts and effusions of serous cavities, thymic uptake, and other non classified causes (4).

In the examination of cutaneous abnormalitites of thyroid dysfunction, interesting similarities were found between cells of melanocytic and thyrocytic origin and thyroid stimulating hormone receptor (TSHR) transcripts have been reported in virtually every cellular component of skin $(10,11)$. According to Ellerhost et al. results, TSH receptors are expressed by almost all cutaneous melanocytic lesions, including benign nevi, dysplastic nevi, and melanomas. In addition, higher expression is observed in malignant and pre-malignant lesions (12).

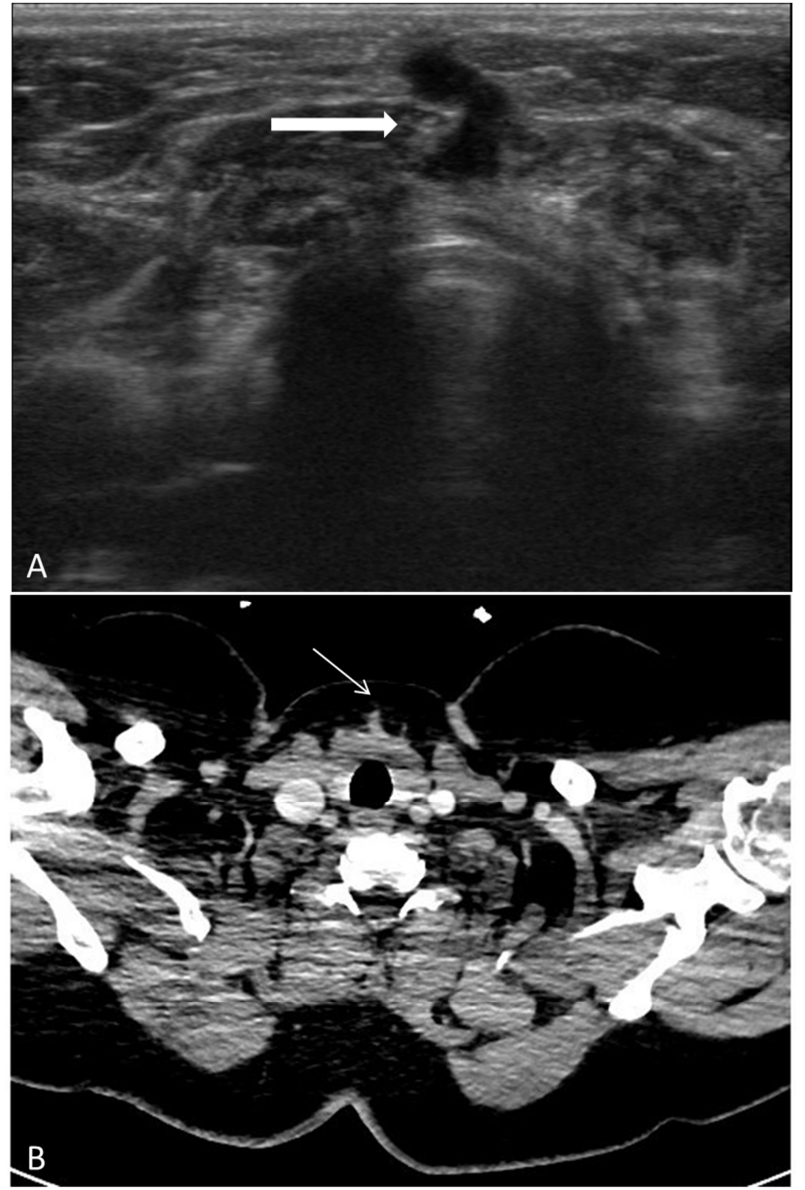

Figure 2: Neck ultrasound (US) showed heterogeneous, hypoechoic, complex, lobulated, solid lesion with milimetric calcifications (suture granuloma) at the thyroid bed and fistula tract extending to the skin (A). Transaxial image of computed tomography revealed fistula tract appearance at the isthmic level of thyroid bed (B)

We report here a newly identified cause of false-positive diagnostic WBS findings with low Tg level: Fistula tract accompanying the SG. SG is clinically important in cancer patients because it can mimic tumor recurrence or metastasis. SG is a rare complication of thyroid surgery and is known to occur after the use of non-absorbable suture materials deep within the skin. The suture material causes specific benign granulomatous inflammatory reactions and almost all SG develop within two years from the operation (13).

The reason of false-positive scans of various inflammatory conditions can be identified with their increased vascularity and capillary permeability. The main cause of non-tumoral pathologic radioiodine uptake is inflammation and this can be caused by any harmful stimuli, such as infection, trauma (16) or infarction.Vasodilation, increased capillary permeability, and humoral and cellular mediators of inflammation may lead to radioiodine accumulation $(2,3,9)$. Abnormal radioiodine accumulation might be observed due to the formation of inflammatory exudates in chronic inflammatory processes stimulated by leucocyte or organification of iodine in leucocytes $(9,14,15,16)$.

Fistula tract extending from operation bed to the skin is a rare complication of thyroid surgery like suture granuloma. In our case, the exact mechanism of radioiodine uptake in the fistula tract couldn't be explained by the above mentioned uptake mechanisms.

US has a high sensitivity in the detection of regional recurrence or nodal metastases in the differentiated thyroid cancer. Additionally, US is one of the main tools used in thyroid cancer follow-up because it is an easy to use and inexpensive method which reveals the importance of US in routine practice (17). CT is mostly used in evaluation of lung and mediastinal metastases. However, it's also used for correlation of suspicious ultrasonographic findings at thyroid bed (18). 


\section{CONCLUSION}

Suture granuloma accompanied by fistula tract is a rare complication of thyroid surgery. The iodine uptake at the suture granuloma is related with chronic inflammation. However, the exact mechanism of iodine-131 uptake of fistula tract is not well known. The case presented here is an example of falsepositive radioiodine uptake caused by the fistula accompanied by the suture granuloma in postoperative thyroid bed because of chronic benign granulomatous inflammatory reaction and to the best of our knowledge, although different false-positive results in 131-I whole-body scintigraphy have been described, it is an interesting case of this kind in the literature. The falsepositive findings in the $1-131$ whole-body scan should be confirmed with other imaging modalities, available biochemical data, clinical history, and physical examination in order to avoid unnecessary treatments.

\section{Conflict of interest}

No conflict of interest was declared by the authors

\section{REFERENCES}

1. Cooper DS, Doherty GM, Haugen BR, Kloss RT, Lee SL, Mandel SJ et al. Revised American Thyroid Association management guidelines for patient with thyroid nodules and differentiated thyroid cancer.Thyroid. 2009;19:1167-214 2. Shapiro B, Ruffini V, Jarwan A, et al. Artifacts, anatomical and physiological variants, and unrelated diseases that might cause false-positive whole-body 131-I scans in the patients with thyroid cancer.Semin Nucl Med.2000;30:115-32 3. Oh JR, Ahn BC. False-positive uptake on radioiodine whole-body scintigraphy: physiologic and pathologic variants unrelated to thyroid cancer.Am J Nucl Med Mol Imaging.2012;2:362-85

4. Buton L, Morel O, Gault P, llouz F, Rodien P, Rohmer V. False-positive iodine131 whole-body scan findings in patients with differentiated thyroid carcinoma: report of 11 cases and review of the literature. Ann Endocrinol 2013;74:221-30.
5. Yildirim-Poyraz N, Özdemir E, Amutkan C, Adiyaman N, Kilinç S, Kandemir Z, et al.False-positive iodine-131 whole body scan due to a benign dermal lesion; intradermal nevus (131 I uptake in a benign nevus). Ann Nucl Med.2013; 278:786-90

6. Gültekin SS, Dilli A, Arıkök AT, Bostancı H, Hasdemir AO. The false-positive radioiodine $1-131$ uptake in the foreign body granuloma located in gluteal adipose tissue. Radiol Oncol 2012;46:28-31

7. Kraft $O$, Sirucek $P$, Mihac L, Havel M. I-131 false positive uptake in a huge parapelvic renal cyst. Nuclear Med Rev 2011;14 :36-7

8. Nair N, Basu S, Pakhale H. Unusual uptake of radioiodine in the chest in a patient with thyroid carcinoma.The British Journal of Radiology 2004,77:63-7

9. Brucher-Davis F, Reynolds JC, Skarulis MC, Fraker DL, Alexander HR, Weintraub BD, et al. False-positive iodine-131 whole-body scans due to cholecystitis and sebaceous cyst.J Nucl Med 1996;37:1690-3

10. Cianfarani F, Baldini E, Cavalli A, Marchioni E, Lembo L, Teson M, et al.TSH receptor and thyroid-specific gene expression in human skin.J Invest Dermatol.2010;130:93-101

11. Leonardt JM, Heymann WR. Thyroid disease and the skin. Dermatol Clin.2002;20:473-81

12. Ellerhorst JA, Sendi-Naderi A, Johnson MK, Cooke CP, Dang SM, Diwan AH. Human melanoma cells express functional receptors for thyroid-stimulating hormone. Endocr Relat Cancer. 2006;13:1269-77

13. Chung YE,Kim EK, Kim MJ, Yun M, Hong SW. Suture granuloma mimicking recurrent thyroid carcinoma on ultrasonography. Yonssei Med J.2006;47:74851

14. Mitchell G, Pratt BE, Vini L, McCready VR,Harmer CL. False-positive 131-I whole-body scans in the thyroid cancer.Br J Radiol 2000;73:627-35

15. Vanden Broek PJ, Buys LFM, Van Furth R.Interaction of povidone-iodine compounds, phagocytic cell and microorganisms.Antimicrob Agents Chemother.1982;22:593-7

16. Regalbuto $C$, Buscema $M$, Arena S, Vigneri R, Squatrito S, Pezzino V. Falsepositive findings on (131) I whole-body scans because of posttraumatic superficial scabs. J Nucl Med. 2002;43:207-9

17. Shin JH, Ko EY. Sonographic Findings in the Surgical Bed After thyroidectomy.J Ultrasound Med 2007;26:1359-66

18. Ahn JE, Lee JH, Yi JS, Shong YK, Hong SJ, Lee DH, et al. Diagnostic accuracy of $\mathrm{CT}$ and ultrasonography for evaluating metastatic cervical lymph nodes in patients with thyroid cancer.World J Surg 2008;32:1552-8 